\title{
EFFECTIVITY OF ERYTHROPOIETIN ALPHA COMPARED TO ERYTHROPOIETIN BETA IN PATIENTS WITH CHRONIC KIDNEY DISEASE-ANEMIA ON HEMODIALYSIS
}

\author{
Anak Agung Ngurah Putra Riana Prasetya ${ }^{1}$, Budi Suprapti ${ }^{2}$, Bayu Dharma Shanti ${ }^{3}$ \\ ${ }^{1}$ Post Graduate Student of Clinical Pharmacy Program, ${ }^{2}$ Clinical Pharmacy Department, Faculty of Pharmacy, \\ Universitas Airlangga, ${ }^{3} \mathrm{Hemodialysis} \mathrm{Unit} \mathrm{of} \mathrm{Bhayangkara} \mathrm{Tk.} \mathrm{II} \mathrm{H.S.} \mathrm{Samsoeri} \mathrm{Mertojoso} \mathrm{Hospital,} \mathrm{Surabaya,}$ \\ Indonesia
}

\section{ABSTRACT}

\begin{abstract}
Anemia in patient with chronic kidney disease could cause a lot of complication. The first line therapy of this condition is by treating with erythropoiesis-stimulating agents (ESA) or called erythropoietin. The erythropoietin alpha and beta were two types of the human recombinant erythropoietin that are usually used in Indonesia. The aim of this study was to determine the effectivity of erythropoietin alpha compared to erythropoietin beta especially in haemoglobin and haematocrit level. This prospective observational study was conducted in March - September 2016. The inclusion criteria were CKD stage 5 patients with a minimum of 3 months of regular hemodialysis, $\mathrm{Hb}<10 \mathrm{~g} / \mathrm{dL}$ with enough iron status $\mathrm{ST}>20 \%$ and FS $>200 \mathrm{ng} / \mathrm{mL}$. The methology of this study had been approved by the Health Research Ethics Committee of the Bhayangkara H.S. Samsoeri Mertojoso Hospital, Surabaya. Patients received $2000 \mathrm{IU}$ subcutaneous erythropoietin twice a week on both groups. Blood sample was withdrawn in pre-treatment and after 4 weeks of post erythropoietin therapy treatment for measurement of haemoglobin and haematocrit. Target for this erythropoietin therapy are increase of $\mathrm{Hb} 0.5-1.5 \mathrm{~g} / \mathrm{dL}$ (not to exceed $12 \mathrm{~g} / \mathrm{dL}$ ) and increase of Hct level $2-4 \%$ in 4 weeks. Based on the inclusion criteria, there were 20 patients in this study (10 patient each of both erythropoietin alpha either beta group) that consist of 7 women and 13 men. After the treatment, the mean of increased haemoglobin level for erythropoietin alpha group was $1.28 \pm 0.80 \mathrm{~g} / \mathrm{dL}(p=0.001)$ and erythropoietin beta was $0.37 \pm 0.95 \mathrm{~g} / \mathrm{dL}(p=0.254)$. The mean of increased haematocrit level for erytropoietin alpha group was $3.56 \pm 3.46 \%(p=0.010)$ and erythropoietin beta was $1.34 \pm 2.71 \%$ ( $p=0.152)$. In comparison of haemoglobin and haematocrit achievement in both groups showed that erythropoietin alpha gave better achievement in haemoglobin parameter $(p=0.033)$, but there were no differences in both groups on haematocrit parameters $(p=0.127)$.
\end{abstract}

Keywords: Eritropoetin; alpha; beta; chronic kidney disease; hemoglobin; hematocrit; ferritin; ST; hemodialysis

ABSTRAK

Anemia pada pasien dengan penyakit ginjal kronis dapat menyebabkan banyak komplikasi. Terapi lini pertama dari kondisi ini adalah mengobati dengan agen-stimulating erythropoiesis (ESA) atau disebut erythropoietin. Erythropoietin alpha maupun beta adalah dua jenis erythropoietin rekombinan manusia yang biasanya digunakan di Indonesia. Tujuan dari penelitian ini adalah untuk mengetahui efektivitas erythropoietin alpha dibandingkan dengan erythropoietin beta terutama pada tingkat hemoglobin dan hematokrit. Penelitian observasional prospektif ini dilakukan pada bulan Maret - September 2016. Kriteria inklusi adalah pasien CKD stadium 5 dengan minimal 3 bulan hemodialisis reguler, $\mathrm{Hb}<10 \mathrm{~g} /$ dL dengan status besi cukup ST >20\% dan FS>200ng/mL. Metodologi penelitian ini telah disetujui oleh Komite Etika Penelitian Kesehatan RS Bhayangkara H.S. Samsoeri Mertojoso Surabaya. Pasien mendapat erythropoietin subkutan 2000 IU dua kali seminggu pada kedua kelompok. Sampel darah diambil dalam pra-perawatan dan setelah 4 minggu perawatan terapi pasca eritropoietin untuk pengukuran hemoglobin dan hematokrit. Target untuk terapi eritropoietin ini adalah peningkatan Hb 0,5 - 1,5 g/dL (tidak melebihi $12 \mathrm{~g} / \mathrm{dL}$ ) dan peningkatan kadar Hct 2 - 4\% dalam 4 minggu. Berdasarkan kriteria inklusi, ada 20 pasien dalam penelitian ini (10 pasien masing-masing dari kedua erythropoietin alfa baik kelompok beta) yang terdiri dari 7 wanita dan 13 pria. Setelah perawatan, rata-rata peningkatan kadar hemoglobin untuk kelompok erythropoietin alpha adalah $1,28 \pm 0,80 \mathrm{~g} / \mathrm{dL}(p=0,001)$ dan erythropoietin beta adalah 0,37 $\pm 0,95$ $g / d L(p=0,254)$. Rerata peningkatan tingkat hematokrit untuk kelompok alpha erytropoietin adalah 3,56 $\pm 3,46 \%(p=0,010)$ dan erythropoietin beta adalah 1,34 $\pm 2,71 \%(p=0,152)$. Sebagai perbandingan pencapaian hemoglobin dan hematokrit pada kedua kelompok menunjukkan bahwa erythropoietin alpha memberikan pencapaian yang lebih baik dalam parameter hemoglobin ( $p=0,033)$, tetapi tidak ada perbedaan pada kedua kelompok pada parameter hematokrit $(p=0,127)$.

Kata kunci: Eritropoetin; alpha; beta; penyakit ginjal kronik; hemoglobin; hematokrit; ferritin; ST; hemodialisis

Correspondence: Anak Agung Ngurah Putra Riana Prasetya, Clinical Pharmacy Program, Faculty of Pharmacy, Univeritas Airlangga. E-mail: gungtra.apoteker95@gmail.com

pISSN:2355-8393 • eISSN: 2599-056x • doi: http://dx.doi.org/10.20473/fmi.v55i2.14330

- Fol Med Indones. 2019;55:82-88 • Received 13 Jul $2017 \bullet$ Accepted 18 Jan 2018

- Open access under CC-BY-NC-SA license • Available at https://e-journal.unair.ac.id/FMI/ 


\section{INTRODUCTION}

Chronic Kidney Disease (CKD) is a kidney damage or decrease of Glomerulous Filtration Rate (GFR) $<60$ $\mathrm{ml} / \mathrm{min} / 1.73 \mathrm{~m}^{2}$ for 3 months (Schonder 2008, O`Callaghan 2009, Lidya 2011). Anemia is a frequent complication in patients with CKD. Based on Perhimpunan Nefrologi Indonesia, anemia interventions start when haemoglobin level is $<10 \mathrm{~g} / \mathrm{dl}$ and the haematocrit level is < 30\% (NKF-K/DOQI 2006, Lidya 2011).

The primary cause of anemia on CKD is insufficient production of erythropoietin which is produced by the kidney. Erythropoietin takes a part in maturity of erytrocyte, proliferation, and its lifetime in interstitial renal peritubuler cells and hepatocyte (Cohan et al 2011). The peptide site on erythropoietin is used for receptor binding and stimulate erythropoiesis, and the carbohydrate site is used to protect itself from clearance. There were 3 type of N-linked olygosacharide (for erythropoietin stabilisation) and one O-linked olygosacharide with none of function (Skibeli et al 2001). There is also 2-4 sialyc acid on the terminal sites of the N-linked olygosacharide that effects on the in vivo for increasing the erythropoietin half life without effecting afinity with their receptors (Elliot 2006).

Based on the structure, the glycan form is dominated by larger tetra-acidic glycans (erythropoietin alpha 19\%, erythropoietin beta $46 \%$, eritropoetin omega $21 \%$ ). This oligosaccharide structure is bigger and more acidic on erythropoietin beta than erythropoietin alpha (Skibeli et al 2001, Deicher et al 2004). Another difference in erythropoietins was bigger bioactivity ratio in vivo : in vitro for erythropoietin beta than alpha (Storring et al, 1998).

Based on pharmacokinetics and pharmacodynamics study of erythropoietin alpha and erythropoietin beta, the steady stage volume distribution and the volume distribution after intravena administration of erythropoietin beta is higher than erythropoietin alpha. Besides, terminal elimination half-life of erythropoietin beta is much longer $(20 \%)$ than erythropoietin alpha (Halstenson et al 1991).

Erythropoietin is given by subcutaneous administration (longer elimination half-life). Erythropoietin dose is 2000-5000 IU each time after haemodialysis or 80-120 IU/kg/week (Lidya 2011). Target of the therapy are increase of haemoglobin level $0.5-1.5 \mathrm{~g} / \mathrm{dL}$ in 4 weeks and increase of haematocrit level about $2-4 \%$ in $2-4$ weeks. The therapy should be considered to stop if the haemoglobin level increase $>13 \mathrm{~g} / \mathrm{dL}$ (Lidya 2011). The aim of this study was to determine the effectivity of erythropoietin alpha compared to erythropoietin beta especially in haemoglobin and haematocrit level.

\section{MATERIALS AND METHODS}

This prospective observational study was conducted in March - September 2016. The patients were diagnosed with CKD stage 5 with a minimum of 3 months of regular hemodialysis, $\mathrm{Hb}<10 \mathrm{~g} / \mathrm{dL}$ with enough iron status ST $>20 \%$ and FS $>200 \mathrm{ng} / \mathrm{mL}$. The methods of this study has been approved by the Health Research Ethics Committee of the Bhayangkara H.S. Samsoeri Mertojoso Hospital, Surabaya. Patients received 2000 IU subcutaneous erythropoietin twice a week on both groups. Blood sample was withdrawn in pre-treatment and after 4 weeks of erythropoietin therapy posttreatment for measurement of haemoglobin and haematocrit.

\section{RESULTS}

Based on the inclusion and exclusion criteria, there were 20 patients (10 patients for each group) comprising 13 men and 7 women. Transferrin Saturation (39.6 \pm 19.78 $\%$ and $36.73 \pm 15.89 \%)$ also ferritin serum level $(680.55 \pm 448.70 \mathrm{ng} / \mathrm{ml}$ and $856.73 \pm 660.19 \mathrm{ng} / \mathrm{ml})$ on all of patients performed adequate iron level to start the erythropoietin therapy.

The weight showed the mean value for erythropoietin alpha group of $59.70 \pm 8.06 \mathrm{~kg}$ and $57.45 \pm 14.21 \mathrm{~kg}$ in erytheropoietin beta group. Patients received the the usual dose of erythropoietin (2000UI) for 8 times, and after the treatment there were 9 patients with low doses percentages (based on minimum adjustment dose based on weight) on erythropoietin alpha and 7 patients on erythropoietin beta. Levene test was used to evaluate the homogeneity and the variance of each groups doses. The results showed there was no dose variance (homogeny), so the dose influence could be ignored for monitoring the haemoglobin and haematocrit result.

After the treatment, the mean of increased haemoglobin level for erythropoietin alpha group was $1.28 \pm 0.80$ $\mathrm{g} / \mathrm{dL}(\mathrm{p}=0.001)$ and erythropoietin beta was $0.37 \pm 0.95$ $\mathrm{g} / \mathrm{dL}(\mathrm{p}=0.254)$. The mean of increased haematocrit level for erythropoietin alpha group was $3.56 \pm 3.46 \%$ $(\mathrm{p}=0.010)$ and erythropoietin beta was $1.34 \pm 2.71 \%$ $(\mathrm{p}=0.152)$.

\section{DISCUSSION}

Both erythropoietins are given by a subcutaneous administration, even though the intravenous 
administration is more comfortable for the patients. This administration was choosed because the subcutaneous administraton would give a longer elimination half life and makes a longer duration of effects (Deicher et al 2004).

Table 1. Patients Characteristics

\begin{tabular}{|c|c|c|}
\hline \multirow{3}{*}{ Characterisics } & \multicolumn{2}{|c|}{ Total Patients $(\mathrm{n}=20)$} \\
\hline & $\begin{array}{l}\text { Epo alpha } \\
(\mathrm{n}=10)\end{array}$ & $\begin{array}{c}\text { Epo beta } \\
(\mathrm{n}=10)\end{array}$ \\
\hline & Total (n) / (\%) & Total (n) / (\%) \\
\hline \multicolumn{3}{|l|}{ Age (years) } \\
\hline$<35$ & $2(20)$ & $2(20)$ \\
\hline $35-44$ & $2(20)$ & $1(10)$ \\
\hline $45-54$ & $4(40)$ & $3(30)$ \\
\hline $55-64$ & $2(20)$ & $3(30)$ \\
\hline$>64$ & - & $1(10)$ \\
\hline Mean \pm SD & $(46.90 \pm 11.60)$ & $(48.50 \pm 14.08)$ \\
\hline \multicolumn{3}{|l|}{ Gender } \\
\hline Men & $6(60)$ & $7(70)$ \\
\hline Women & $4(40)$ & $3(30)$ \\
\hline \multicolumn{3}{|l|}{ Weight $(\mathrm{kg})$} \\
\hline$<50$ & $1(10)$ & $3(30)$ \\
\hline $50-60$ & $4(40)$ & $4(40)$ \\
\hline$>60$ & $5(30)$ & $3(30)$ \\
\hline Mean \pm SD & $(59.70 \pm 8.06)$ & $(57.45 \pm 14.21)$ \\
\hline Hb level (g/dl) & & $3(30)$ \\
\hline $7,0-7,9$ & $7(70)$ & $3(30)$ \\
\hline $8,0-8,9$ & $3(30)$ & $4(40)$ \\
\hline $9,0-9,9$ & - & - \\
\hline Mean \pm SD & $(7.96 \pm 0.37)$ & $(84 \pm 0.86)$ \\
\hline \multicolumn{3}{|l|}{ Hct level (\%) } \\
\hline $10-20$ & - & - \\
\hline $21-30$ & $10(100)$ & $10(100)$ \\
\hline Mean \pm SD & $(23.24 \pm 1.27)$ & $(25.32 \pm 2.52)$ \\
\hline \multicolumn{3}{|l|}{ Ferritin (ng/dL) } \\
\hline$<100$ & - & - \\
\hline $100-500$ & $3(30)$ & $3(30)$ \\
\hline$>500$ & $7(70)$ & $7(60)$ \\
\hline Mean \pm SD & $(39.60 \pm 19.78)$ & $(36.73 \pm 15.89)$ \\
\hline \multicolumn{3}{|l|}{ Transferrin } \\
\hline Saturation (\%) & - & - \\
\hline$<20$ & $7(70)$ & $7(70)$ \\
\hline $20-40$ & $3(30)$ & $3(30)$ \\
\hline$>40$ & $(680.55 \pm 448.70)$ & $(856.73 \pm 660.19)$ \\
\hline \multicolumn{3}{|l|}{ Mean \pm SD } \\
\hline & & $1(10)$ \\
\hline Adverse effect & - & $1(10)$ \\
\hline Headache & - & $1(10)$ \\
\hline Nause/vomiting & - & \\
\hline Diarrhoea & & \\
\hline
\end{tabular}

Target for this therapy was the increase of haemoglobin level about $0.5-1.5 \mathrm{~g} / \mathrm{dL}$ in 4 weeks (not to exceed 12 $\mathrm{g} / \mathrm{dL}$ ). Table 2 and 3 show that the mean increased haemoglobin level on erythropoietin alpha was $1.28 \pm$ $0.80 \mathrm{~g} / \mathrm{dl}(\mathrm{p}=0.001)$, and only $0.37 \pm 0.95 \mathrm{~g} / \mathrm{dl}$ on erythropoietin beta groups $(\mathrm{p}=0.254)$. Other study also showed that there were no differences between haemoglobin level before therapy and after 3-6 months therapy of erythropoietin alpha and beta by the intravenous administrartion (Ostrvica et al 2010). This therapy also has been expected to increase the haematocrit level about $2-4 \%$ in 4 weeks (Lydia 2011). Table 2 and 3 show the mean increased haematocrit level on erythropoietin alpha groups about $3.56 \pm 3.46 \%(\mathrm{p}=0.010)$, and about $1.34 \pm 2.71 \%$ for erythropoietin beta groups $(\mathrm{p}=0.152)$. Other study also showed that there were no differences between haematocrit level before therapy and after 3-6 months therapy of erythropoietin alpha and beta by the intravenous administrartion (Ostrvica et al 2010). The measurement of haemoglobin gave a better result than haematocrit because haemoglobin gave a real direct oxygen capacity, but not with haematocrit that can be influenced by such condition, such as diabetic, that can make refraction result for the measurement (Kasiske 2012).

Fig. 1 shows that there is a differences on increase Haemoglobin parameter (better in erythropoietin alpha, $\mathrm{p}=0.033$ ), but neither differences in both groups on changes of Haematocrit $(p=0.127)$. The main cause of this result was iron status, malnutrition, inadequacy of hemodialysis, inflammation, and usage of Angiotension Receptor Blocker (ARB) drugs.

Adequacy of iron status showed good results for the initial of erythropoietin therapy, although a high Transferrin Saturation $>80 \%$ would make a lot nontransferrin bound iron that could effect a damage to hepatocyte and cardiac myosite (Ganz \& Nemet 2015). Higher Ferritin Serum level could be caused by infection, inflamation, and transfussion. Also, Transferrin level may be affected by diurnal variation (Febrianti 2011, Ganz \& Nemet 2015). Whereas, in an accute response phase, there were cytokines pro inflammation, such as interleukin-1 B1 (IL1-ß1) and TNF-a, that could increase the ferritin mRNA translation. Thus, changes would affect the hepcidin activity, furthermore would decrease iron release and iron absorption in duodenum. (Ganz \& Nemet 2015, Febrianti 2011). 
Table 2. Distribution of Haemoglobin Level on Epo Alpha and Epo Beta Groups

\begin{tabular}{|c|c|c|c|c|c|c|c|c|c|c|c|}
\hline \multicolumn{6}{|c|}{ Epo Alpha } & \multicolumn{6}{|c|}{ Epo Beta } \\
\hline $\begin{array}{l}\text { Patient } \\
\text { Code }\end{array}$ & $\begin{array}{c}\text { Weight } \\
(\mathrm{kg})\end{array}$ & $\begin{array}{c}\text { Epo Dose* } \\
(\%)\end{array}$ & $\begin{array}{l}\text { Hb pre } \\
(\mathrm{g} / \mathrm{dL})\end{array}$ & $\begin{array}{c}\text { Hb post } \\
\text { (g/dL) }\end{array}$ & $\Delta \mathrm{Hb}$ & $\begin{array}{c}\text { Patient } \\
\text { Code }\end{array}$ & $\begin{array}{c}\text { Weight } \\
(\mathrm{kg})\end{array}$ & $\begin{array}{c}\text { Epo Dose } \\
(\%)\end{array}$ & $\begin{array}{l}\text { Hb pre } \\
(\mathrm{g} / \mathrm{dL})\end{array}$ & $\begin{array}{l}\text { Hb post } \\
\text { (g/dL) }\end{array}$ & $\Delta \mathrm{Hb}$ \\
\hline $1 \mathrm{~A}$ & 51 & 98 & 8.5 & 8.9 & 0.4 & 1B & 75 & 67 & 9.5 & 11 & 1.5 \\
\hline $2 \mathrm{~A}$ & 65.5 & 76 & 7.8 & 9.6 & 1.8 & $2 \mathrm{~B}$ & 42 & 119 & 8.3 & 10.1 & 1.8 \\
\hline $3 \mathrm{~A}$ & 53 & 94 & 7.9 & 9.7 & 1.8 & 3B & 56 & 89 & 9.8 & 8.7 & -1.1 \\
\hline $4 \mathrm{~A}$ & 67.5 & 74 & 7.8 & 10.7 & 2.9 & $4 \mathrm{~B}$ & 54 & 93 & 7.4 & 7.1 & -0.3 \\
\hline $5 \mathrm{~A}$ & 60 & 83 & 7.8 & 8.7 & 0.9 & $5 \mathrm{~B}$ & 38 & 132 & 9.3 & 10.1 & 0.8 \\
\hline $6 \mathrm{~A}$ & 68 & 74 & 7.8 & 8.3 & 0.5 & $6 \mathrm{~B}$ & 82 & 61 & 9.0 & 10 & 1 \\
\hline $7 \mathrm{~A}$ & 47 & 106 & 8.5 & 8.9 & 0.4 & $7 \mathrm{~B}$ & 58 & 86 & 7.4 & 7.9 & 0.5 \\
\hline $8 \mathrm{~A}$ & 65.5 & 76 & 7.3 & 8.4 & 1.1 & $8 \mathrm{~B}$ & 60 & 83 & 7.8 & 7.3 & -0.5 \\
\hline $9 \mathrm{~A}$ & 67 & 74 & 7.9 & 9.1 & 1.2 & $9 \mathrm{~B}$ & 43.5 & 115 & 8.2 & 8.8 & 0.6 \\
\hline $10 \mathrm{~A}$ & 52.5 & 95 & 8.3 & 10.1 & 1.8 & $10 \mathrm{~B}$ & 66 & 76 & 8.7 & 8.1 & -0.6 \\
\hline $\begin{array}{c}\text { Mean } \pm \\
\text { SD }\end{array}$ & $\begin{array}{c}59.7 \pm \\
8.06 \\
\end{array}$ & $\begin{array}{c}85 \pm \\
12.11 \\
\end{array}$ & $\begin{array}{c}7.96 \pm \\
0.37 \\
\end{array}$ & $9.24 \pm 0.77$ & $\begin{array}{c}1.28 \pm \\
0.80 \\
\end{array}$ & $\begin{array}{c}\text { Mean } \pm \\
\text { SD }\end{array}$ & $\begin{array}{c}57.45 \pm \\
14.21 \\
\end{array}$ & $\begin{array}{r}92.1 \pm \\
23.16 \\
\end{array}$ & $\begin{array}{c}8.54 \pm \\
0.86 \\
\end{array}$ & $8.91 \pm 1.33$ & $0.37 \pm 0.95$ \\
\hline Paired $t-t$ & \multicolumn{5}{|c|}{$\mathrm{P}=0.001$} & \multicolumn{6}{|c|}{$P=0.254$} \\
\hline
\end{tabular}

Independent t-test

$\mathrm{P}=0.033$

Annotation: $\mathrm{p}<0.05$ : valuable differences

*: base on minimum dose by weight $(80-120 \mathrm{IU} / \mathrm{kg} /$ week $)$

Table 3. Distribution of Haematocrit Level on Epo Alpha and Epo Beta Groups

\begin{tabular}{cccccc}
\hline \multicolumn{6}{c}{ Epo Alpha } \\
\hline $\begin{array}{c}\text { Patient } \\
\text { Code }\end{array}$ & $\begin{array}{c}\text { Weight } \\
(\mathrm{kg})\end{array}$ & $\begin{array}{c}\text { Epo Dose } \\
(\%)\end{array}$ & $\begin{array}{c}\text { Hct pre } \\
(\mathrm{g} / \mathrm{dL})\end{array}$ & $\begin{array}{c}\text { Hct post } \\
(\mathrm{g} / \mathrm{dL})\end{array}$ & $\Delta \mathrm{Hb}$ \\
\hline 1A & 51 & 98 & 24.5 & 27.1 & 2.6 \\
2A & 65.5 & 76 & 22.5 & 27.9 & 5.4 \\
3A & 53 & 94 & 22.5 & 28.7 & 6.2 \\
4A & 67.5 & 74 & 23 & 32.1 & 9.1 \\
5A & 60 & 83 & 23 & 26.2 & 3.2 \\
6A & 68 & 74 & 21.9 & 23.7 & 1.8 \\
7A & 47 & 106 & 25.5 & 25.5 & 0 \\
8A & 65.5 & 76 & 21.9 & 19.2 & -2.7 \\
9A & 67 & 74 & 22.7 & 25.9 & 3.2 \\
10A & 52.5 & 95 & 24.9 & 31.7 & 6.8 \\
\hline Mean \pm & $59.7 \pm$ & $85 \pm$ & $23.24 \pm 1.27$ & $26.8 \pm 3.76$ & $3.56 \pm$ \\
SD & 8.06 & 12.11 & & 3.46 \\
\hline Paired t-test & \multicolumn{5}{c}{$\mathrm{P}=0.010$}
\end{tabular}

\begin{tabular}{cccccc}
\hline $\begin{array}{c}\text { Patient } \\
\text { Code }\end{array}$ & $\begin{array}{c}\text { Weight } \\
(\mathrm{kg})\end{array}$ & $\begin{array}{c}\text { Epo Dose } \\
(\%)\end{array}$ & $\begin{array}{c}\text { Hct pre } \\
(\mathrm{g} / \mathrm{dL})\end{array}$ & $\begin{array}{c}\text { Hct post } \\
(\mathrm{g} / \mathrm{dL})\end{array}$ & $\Delta$ Hct \\
\hline 1B & 75 & 67 & 27 & 30.4 & 3.4 \\
2B & 42 & 119 & 25.7 & 31.5 & 5.8 \\
3B & 56 & 89 & 28 & 26.2 & -1.8 \\
4B & 54 & 93 & 21.6 & 21.4 & -0.2 \\
5B & 38 & 132 & 27.3 & 31.6 & 4.3 \\
6B & 82 & 61 & 28.9 & 31.6 & 2.7 \\
7B & 58 & 86 & 23.4 & 24 & 0.6 \\
8B & 60 & 83 & 22.9 & 22.0 & -0.9 \\
9B & 43.5 & 115 & 22.7 & 24.5 & 1.8 \\
10B & 66 & 76 & 25.7 & 23.4 & -2.3 \\
\hline Mean \pm & $57.45 \pm$ & $92.1 \pm$ & $25.32 \pm 2.52$ & $26.67 \pm$ & $1.34 \pm$ \\
SD & 14.21 & 23.16 & \multicolumn{4}{c}{$\mathrm{P}=0.152$} & \\
\hline \multicolumn{5}{c}{}
\end{tabular}

Independent t-test

$\mathrm{P}=0.127$

Annotation: $\mathrm{p}<0.05$ : valuable differences 
*: base on minimum dose by weight $(80-120 \mathrm{IU} / \mathrm{kg} /$ week $)$

Table 4. Increased of Haemoglobin and Haematocrit Level in Erythropoietin Alpha and Erythropoietin Beta Groups

\begin{tabular}{|c|c|c|c|c|c|c|c|c|c|c|c|}
\hline \multicolumn{6}{|c|}{ Erythropoietin Alpha } & \multicolumn{6}{|c|}{ Erythropoietin Beta } \\
\hline Patient Code & $\begin{array}{c}\text { Epo Dose } \\
(\%)^{*}\end{array}$ & $\Delta \mathrm{Hb}^{* *}$ & $\Delta \mathrm{Hct}^{* * *}$ & Target $\mathrm{Hb}$ & Target Hct & Patient Code & $\begin{array}{c}\text { Epo Dose } \\
(\%)^{*}\end{array}$ & $\Delta \mathrm{Hb}^{* *}$ & $\Delta \mathrm{Hct}^{* * *}$ & Target $\mathrm{Hb}$ & $\begin{array}{c}\text { Target } \\
\text { Hct }\end{array}$ \\
\hline $1 \mathrm{~A}$ & 98 & 0.4 & 2.6 & - & + & $1 \mathrm{~B}$ & 67 & 1.5 & 3.4 & + & + \\
\hline $2 \mathrm{~A}$ & 76 & 1.8 & 5.4 & + & + & $2 \mathrm{~B}$ & 119 & 1.8 & 5.8 & + & + \\
\hline $3 \mathrm{~A}$ & 94 & 1.8 & 6.2 & + & + & $3 B$ & 89 & -1.1 & -1.8 & - & - \\
\hline $4 \mathrm{~A}$ & 74 & 2.9 & 9.1 & + & + & $4 \mathrm{~B}$ & 93 & -0.3 & -0.2 & - & - \\
\hline $5 \mathrm{~A}$ & 83 & 0.9 & 3.2 & + & + & $5 B$ & 132 & 0.8 & 4.3 & + & + \\
\hline $6 \mathrm{~A}$ & 74 & 0.5 & 1.8 & + & - & $6 \mathrm{~B}$ & 61 & 1 & 2.7 & + & + \\
\hline $7 \mathrm{~A}$ & 106 & 0.4 & 0 & - & - & $7 \mathrm{~B}$ & 86 & 0.5 & 0.6 & + & - \\
\hline $8 \mathrm{~A}$ & 76 & 1.1 & -2.7 & + & - & $8 \mathrm{~B}$ & 83 & -0.5 & -0.9 & - & + \\
\hline $9 \mathrm{~A}$ & 74 & 1.2 & 3.2 & + & + & $9 \mathrm{~B}$ & 115 & 0.6 & 1.8 & + & - \\
\hline \multirow[t]{2}{*}{$10 \mathrm{~A}$} & 95 & 1.8 & 6.8 & + & + & $10 \mathrm{~B}$ & 76 & -0.6 & -2.3 & - & - \\
\hline & 85 & 1.28 & 3.56 & & & \multirow{3}{*}{ Mean \pm SD } & 92.1 & 0.37 & 1.34 & & \\
\hline \multirow[t]{2}{*}{ Mean \pm SD } & \pm & \pm & \pm & & & & \pm & \pm & \pm & & \\
\hline & 12.11 & 0.80 & 3.46 & & & & 23.16 & 0.95 & 2.71 & & \\
\hline
\end{tabular}

*suitable dose based on NKF-KDOQI and PERNEFRI (80 U/BB/week)

**increased of Haemoglobin target level(NKF-KDOQI and PERNEFRI is $0.5-1.5 \mathrm{~g} / \mathrm{dl}$ in 4 weeks

$* * *$ increased of Haemaocrit target level (NKF-KDOQI and PERNEFRI is $2-4 \%$ in 4 weeks

+Target therapy reached

-Target therapy did not reached 


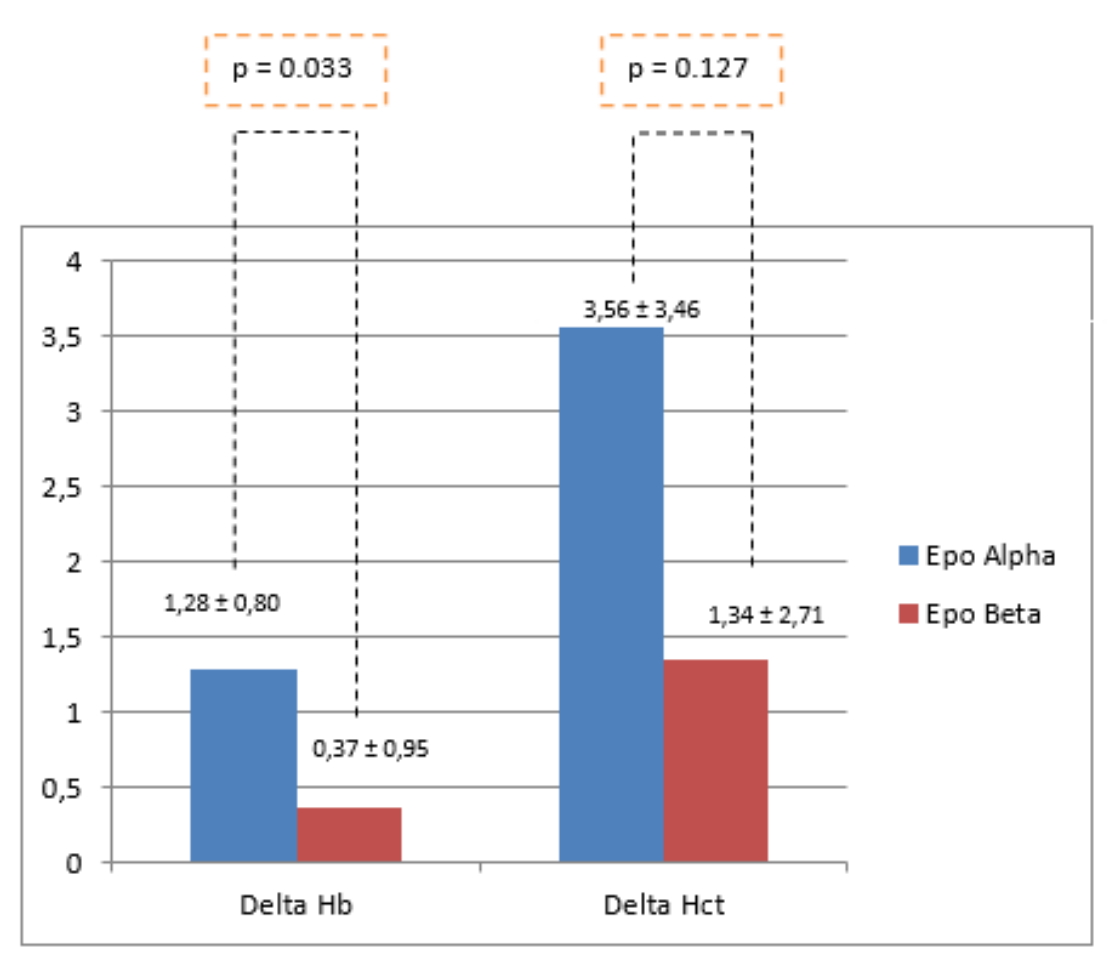

Fig. 1. Increased haemoglobin and haematocrit level in Epo Alpha and Epo Beta Groups.

There is inadequacy effect of the underdose $2000 \mathrm{IU}$ therapy of both erythropoietins. As thought that, there should be a better study to see the effect on haemoglobin and haematocrit with a measurement of adjustment dose by the weight of each patient. In our next analysis, from the levene statistical shows that was no dose variation on both group (homogen) $\mathrm{p}=0.113$ so that the influence of dose variation could be dismissed. By the effect of inflamation on this study, there were only an Sedimentation Blood Rate (SBR), which had kind of check the CRP on each patient. Its because the Sedimentation Blood Rate could be caused by a lot of thing that could not be measure like physiological stress (Wilson 2008).

By the evaluation of malnutrition factor, there were limited data (only the evaluaton by Body Mass Index). There should be a better evaluation, such as monitoring albumin level on patients. Patients also got Angiotensin Receptor Blockers that can effect permorming on increase targeting therapy. ARB leads to anemia by blockade the direct effect of Angiotensin II on Erythroid Precursor Cells for erythropoiesis and also thus effect by vasodilatation on kidney efferent vessel (Mohanram 2007).

Uremic condiditon also leads to worsening anemi on patients. Uremic could shortened the lifetime of the erythrocyte from normal 120 days to 45-85 days. It's because there were a decrease level of glutation as an antioxidant that can leads to weakeness of the erythrocyte and make a damage to it (Greene et al 2008, Kruske et al 2008). On this study there was not any comperehensive data for the Blood Ureum Nitrogen, and Creatinin Serum was just at a random measurement.

\section{CONCLUSION}

Erythropoietin alpha gave better achievement in inreasing haemoglobin parameter than erythropoietin beta, but there were differences in both groups on changes of haematocrit parameters.

\section{REFFERENCES}

Cohan RA, Madadkar-Sobhani A, Khanahmad H, Roohvand F, Aghasadeghi MR, Hedayati MH, et al (2011). Design, modelling, expression, and chemoselective PEGylation of a new nanosize cystein analog of erythropoietin. International Journal of Nanomedicine 6, 1217-1221

Deicher, Robert WH, Hurl (2004). Differentiating factors between erytheopoiesis-stimulating agents. 
Austria, Division of Nephrology and Dialysis, Departement of Medicine III, University of Vienna

Elliott SG (2006). New molecules and formulations of recombinant human erythropoietin, In: Molineux G, Foote MA, Elliott SG (Eds), Erythropoietins and Erythropoiesis. Berlin, Birkhäuser Verlag/Switzerland Basel, p 244-245

Febriyanti AP (2011). Peningkatan kadar hemoglobin paska pemberian eritropoetin pada pasien penyakit ginjal kronik-anemia dengan hemodialisis. Surabaya

Ganz, Nemeth (2015). Iron homeostasis in host defence and inflammation. Nat Rev Immunol 15, 500-510

Greene RJ, Harris NO, Goodyer LI (2008). Pathology and therapeutics for pharmacist. A Basic for Clinical Pharmacy Practice. 3rd Ed. London, Pharmaceutical Press, p 908-910

Halstenson CE, Macres M, Kats Sa, et al (1991). Comparative pharmacokinetics and pharmacodynamics of epoetin alpha and epoetin beta. Clinical Pharmacology Therapy 50, 702-12

Kasiske BL (2012). Clinical practice guideline for the evaluation and management of chronic kidney disease on national kidney foundation kidney disease improving global outcome guideline for chronic kidney disease.

KDOQI (2006). Clinical practice guideline and clinical practice recommendations for anemia in chronic kidney disease: $\mathrm{Hb}$ range. American Journal of Kidney Diseases 47, S33-S53

Kruske, Anja, Uehlinger DE, Gotcha, Frank, Kotankoa, Peter, Levina NW (2008). Red blood cell lifespan, erythropoiesis and hemoglobin control. In: Ronco C,
Cruz DN (eds). Hemodialysis - From Basic Research to Clinical Trials. Switzerland, Karger 161, 247-254

Lydia (2011). Konsensus manajemen anemia pada penyakit ginjal kronis: Perhimpunan Nefrologi Indonesia. Jakarta.

Mohanram A, Zhang Z, Shahinfar S, Lyle PA, Toto RD (2007). The effect of losartan on hemoglobin concentration and renal outcome in diabetic nephropathy of type 2 diabetes. Kidney International. Indianapolis, Internal Society of Nephrology, p 630

O'Callaghan CA (2009). The renal system at a glance. 3rd Ed. England, John Wiley \& Sons Publication, $p$ 34-35

Ostrvica E, Mesic E, Ostrvica D, Delic J, Custendil SC, Hukic F (2010). Effectiveness of treating the renal anemia in chronic hemodialyzed patients by epoietin alpha and beta. Boznia and Herzegovina, Med Arch, p 4-6

Schonder KS (2008). Chronic and end-stage renal disease. In: Dipiro, J. T(Eds), Pharmacotherapy principles \& practice. New York, The McGraw-Hill Companies, Inc., p 373-386

Skibeli V, Nissen-Lie G, Torjesen P (2001). Sugar profiling proves that human serum erythropoietin differs from recombinant human erythropoietin, Blood 98, 3626

Storring PL, Tiplady RJ, Gaines DRE (1998). Epoetin alpha and beta differ in their erythropoietin isoform compositions and biological properties. British Journal Haematology 100, 79-89

Wilson DD (2008). Mcgraw-Hill's manual of laboratory \& diagnostic tests. New York, The Mcgraw-Hill Companies, p 237 